\title{
Developing A Superior Business Strategy Through Industrial Environment And Resources In Manufacturing Smes In West Java Province
}

\author{
Kania Agustina ${ }^{1}$, Otong Karyono ${ }^{2}$ \\ ${ }_{1,2}$ Postgraduate-Majalengka University \\ otong.karyono@gmail.com
}

\begin{abstract}
Developing a superior business strategy in manufacturing Usaha Kecil dan Menengah (UKM) or Small and Medium-sized Enterprises (SMEs)is an important and fundamental instrument in answering the existing high competitiveness challenge. One of which is by implementing a business strategy that is adjusted tothe resources provision and the aspect of industrial environment to realise the superior business strategy. This research is a quantitative research with the analysis technique used is path analysis. The results of the analysis showed that the implementation of the business strategy is highly influenced by the industrial environmental factor and the resources provision owned by the manufacturing SMEs.
\end{abstract}

Keywords: Industrial environment; resources; business strategy environment.

\section{Introduction}

The role of SMEs in Asia Pacific region tends to be more significant. Data from Bank Pembangunan Asia (ADB) in adb.org page shows that themajority of SMEs contributesup to $62 \%$ of the employment with a population of around 96 percent from the total companies in 20 countries in the Asia Pacific region (Primus, 2019). In Indonesia, the contribution of micro, small, and medium business sector towards gross domestic product escalates from $57.84 \%$ to $60.34 \%$ in the last five years. Labor absorptionin this sector also increases from 96.99\% to $97.22 \%$ (Kemenperindag 2019) (Kompas, 28/01/2019). In a journal (Akbar, 2015) explains that SMEs plays a significant role in Indonesian economy, in terms of the number of the enterprises (establishment) and job creation.

SMEs of food and baverage processing in West Java Province cannot avoid the competition that is getting complex and significant, specifically when it is faced with the condition of globalisation and free trade flow that is marked by the presence of AFTA (Asian Free Trade Area). It becomes a challenge for a business unit, including SMEs, to be more responsive toward such instability. The flow of globalisation and AFTA provide contrast effect to the consumer behaviour. The consumers are smarter and more conscientious in every purchase of a product, so that it makes the consumers' taste always fluctuative towards a product's demand caused by the environmental situation that keeps changing. SMEs in West Java Province still face a dilemmatic problem which is as the main fuel of the economic wheels in this province. However, the SMEs' condition is not yet optimal today to compete nationally. From the results of inventory towards the problem of manufacturing SMEs in West Java Province, it is obtained some indicators that are predicted as the cause of the low competitive ability, as described in Figure 1. 


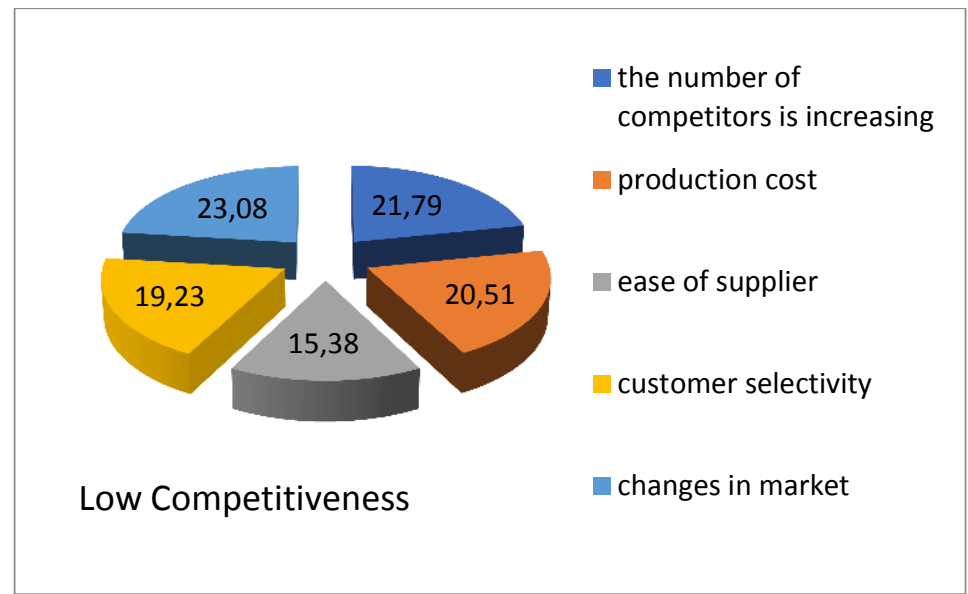

Figure 1. Preliminary Research towards Industrial Environmental Variable

Industrial environment as a macro environment plays a role in accelerating the environmental change. The industrial environment refers to the buyers' bargaining power. Meanwhile, five factors including the sellers' bargaining power, the presence of potential new comers, the existence of substitute goods, and the intensity of corporate competition in an industry are known as competing power(Porter, 1998). Meanwhile, an internal environment consists of structure, culture, and resources (Hunger \& Wheelen, 2012).

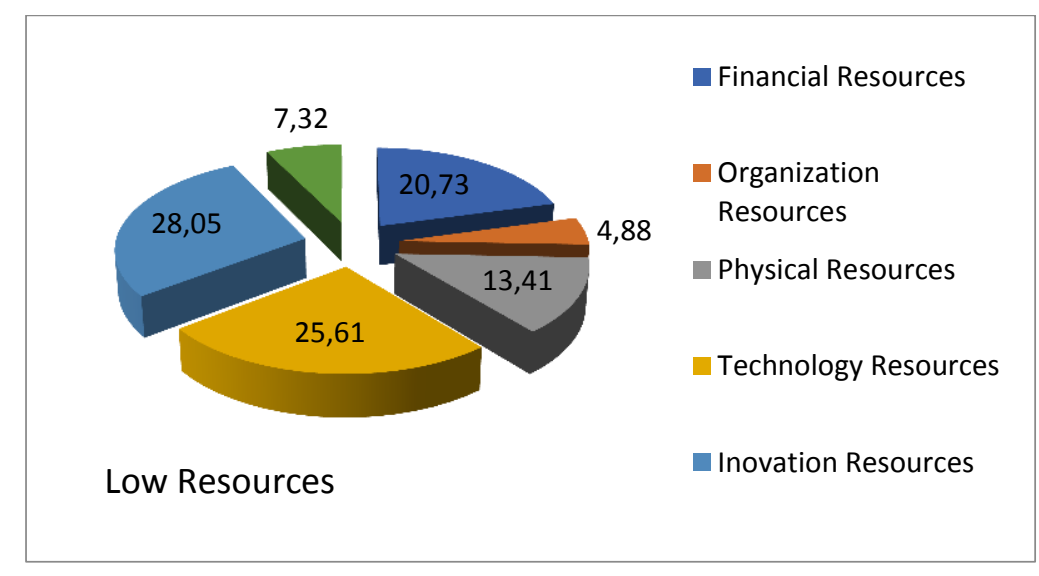

Figure 2. Preliminary Research towards Industrial Environmental Variable

Based on Figure 2, it is concluded that the condition of resources in SMEs in West Java Province is considered not yet fully maximal and still has limitations. "The limitation of resources that is faced by the SMEs manager influences the business performance" (Elizabeth, 1998), which is measured by the rotation and increased employment of labour (Mäki \& Pulkkinen, 2000; Georgellis, Yannis, Joyce, Paul, \& Woods, 2000), and traditionally stated in financial terminology (Laitinen, 2002; De Toni, 1998). Industrial environment and resources are input from a strategy that will be implemented, so that the role and function of the industrial environment andresources become important in order to achieve the effectivity of the implemented strategy. Referring to the condition elaborated above, 
research needs to be conducted on the implementation of SMEs business strategy through the input of industrial environment and resources.

\section{II.Literature Review}

Industrial environment is the environment around the industry that includes a set of threat factors from new business managers, suppliers, buyers, substitute goods, and competition intensity among the competitors that directly affects the company, its actions, and competitive responses. Olarewaju, Technology, and Folarin (2012), Indris and Primiana (2015), and Njoroge, Ongeti, and Kinuu (2016) in their research show that the industrial environment, both from internal and external, plays a significant role in determining performance of the company. Resources are the internal environment that have unique characteristics compared to other factors since resources are the basis of strength in stimulating other functions or factors. The use of resources has many potential advantages for the company such as the achievement of greater efficiency which requires lower cost, quality escalation, possible market share, and higher profitability (Collis, 1994). Resources are one trigger to strengthen competing strategy, but some problems are still found in the aspect of resources, especially for technology resources, innovation resources, and financial resources.

\section{Methodology}

The method used in this research was survey method with explanatory research. Survey method is a research method that is implemented to obtain several existing facts and phenomena, and seek factual information. Hence, the method is advantageous to reveal and discuss problems, and obtain justification towards the continuing practices. Moreover, by implementing the survey method, evaluation and comparison toward what people do to deal with similar situation or problemcan be done and the results can be used forplanning arrangement and decision making in the future.In accordance with its purpose, this research explains causal relationship among the research concepts and tests a hypothesis to take a decision inductively or with generalisation,so this research is explanatory research. In this research, a test towards previously formulated hypothesis among the variables of the industrial environment, resources, and business strategies in West Java Provincewas conducted. The analysis technique that was used in this research was path analysis. The path analysis was used since this analysis was more comprehensive and able to analyse the whole models that were previously designed by the researchers, while the regression analysis tended to be partial. Therefore, the most appropriate and ideal analysis technique for this research was path analysis. The construct of relation (path of research)is described in Figure 3: 
Figure information :

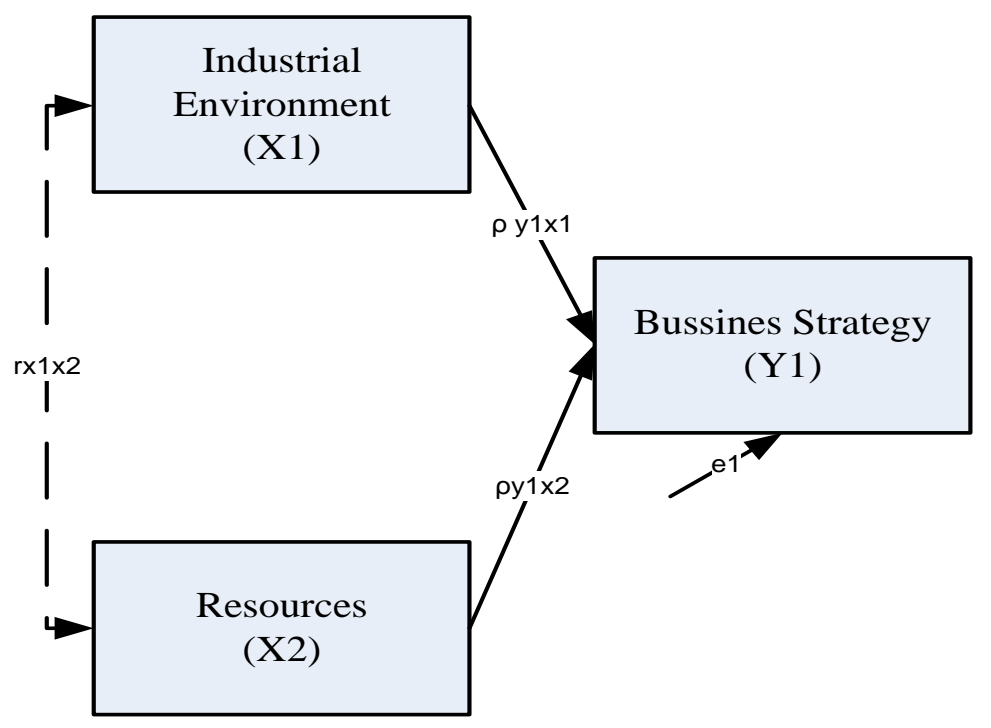

Figure 3.The Structure of Path Analysis

X1 = Industrial Environment: (LI 1 = Rivalry among competitors, LI 2 = Business Costs, LI 3 = Supplier Strength, LI 4 = Customer Strength, LI5 = Market Dynamism)

$\mathrm{X} 2$ = Resources: (SD 1 = Financial resources; SD2 = Organisational resources; SD3 = Physical resources; SD4 $=$ Technology resources, SD5 = Human resources; SD6 = Innovation resources, $\mathrm{SD} 7=$ Reputation resources)

$\mathrm{Y} 1=$ Implementation of business strategy $(\mathrm{SB} 1=$ Strategy of cost advantage, SB2 = Strategy of differentiation, SB3 = Strategy of focus)

$\varepsilon=$ Epsilon

The equation for path analysis is $\rho_{\mathrm{Y} 1 \mathrm{X} 1}, \rho_{\mathrm{Y} 1 \mathrm{X} 2}, \rho_{\mathrm{Zy} 1} \rho_{\mathrm{zY} 2}$, which resultspath coefficient. The structure of variable relation can be stated in a regression equation :

$Y=b_{0}+b_{1} X_{1}+b_{2} X_{2}+b_{n} X_{n}$

Path coefficient can be identified from the formula:

pyxi $=$ byxi $\sqrt{\frac{\sum_{h=1}^{n} X i h}{\sum_{h=1}^{n} X_{i h h}^{2}}}, i=1$ dan 2

and regression coefficient, $\mathrm{b}_{0}, \mathrm{~b}_{1}$, dan $\mathrm{b}_{2}$ can be calculated with the formula :

$b=\left|\begin{array}{l}b_{0} \\ b_{1} \\ b_{2}\end{array}\right|=\left(X^{T} X\right)^{-1} X^{T} Y$

For the purpose of path analysis, variable standardisation and collinearity testing were used. Based on the purpose of this research, the analysed variables were independent 
variables, including Industrial Environment $\left(\mathrm{X}_{1}\right)$ and Resources $\left(\mathrm{X}_{2}\right)$, and the Implementation of Business Strategy $\left(\mathrm{Y}_{1}\right)$ as the dependent variable.

\section{Discussion}

The results of the path analysis in this study related to the industrial environment and resources and their influence on the implementation of business strategyare as follows.

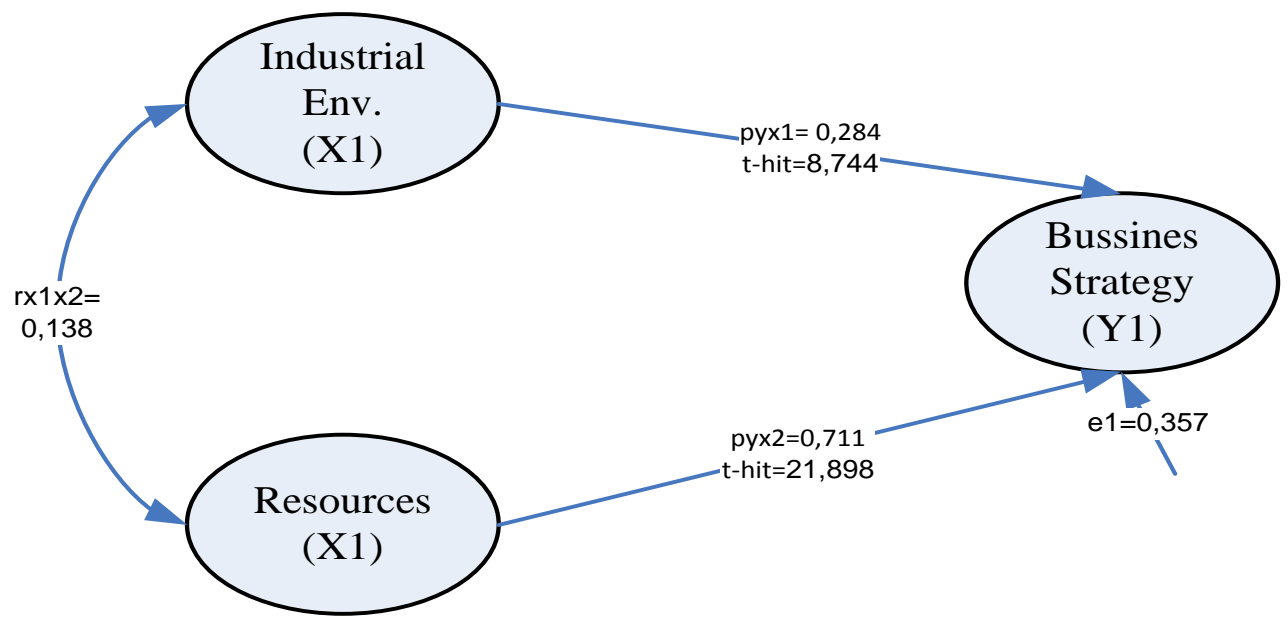

Figure 4. Path Diagram of Industrial Environment and Resources towards Business Strategy

From Figure 4, it is known that the variables of industrial environment and resources are correlatedto each other. Even its correlation level is signficantly low, but it still shows positive number.

Table 1. Correlation Coefficient

\begin{tabular}{|l|l|}
\hline \multicolumn{1}{|c|}{ Correlation $(\mathbf{r})$} & \multicolumn{1}{c|}{ Indication } \\
\hline Between, \pm 80 to 1,00 & High correlation \\
Between, \pm 60 to, 79 & Moderately high correlation \\
Between, \pm 40 to, 59 & Moderate correlation \\
Between, \pm 20 to, 39 & Low correlation \\
Between,$\pm \mathbf{0 1}$ to, $\mathbf{1 9}$ & Negligible correlation \\
\hline
\end{tabular}

Source: (Sudjana, 2003)

From the variable correlation between Industrial Environment $\left(\mathrm{X}_{1}\right)$ and Resources $\left(\mathrm{X}_{2}\right)$, the correlation coefficient value of 0.138 is obtained. Therefore, it can be stated that the relation between those two variables is positivewith the closeness criterion of Negligible Correlation (Very low). The first hypothesis testing is carried out simultaneously intended to test the hypothesis of $\mathrm{Y}_{1}$ variable (the implementation of business strategy) which is influenced simultaneously by the industrial environment $\left(\mathrm{X}_{1}\right)$ and resources $\left(\mathrm{X}_{2}\right)$ variables. The test is carried out with the coefficient of determination test by using a significance test 
that is done with the help SPSS version 17. Then to test it, the following statistical hypothesis would be used:

$$
\begin{aligned}
& \mathrm{H}_{0}:\left(\rho_{\mathrm{yx}}\right)=0 \quad: \text { There is no influence from the industrial environment and } \\
& \text { resources towards the implementation of business } \\
& \text { strategies. } \\
& \mathrm{H}_{1}:\left(\rho_{\mathrm{yx}}\right) \neq 0 \quad \begin{array}{l}
\text { There is influence from the industrial environment and } \\
\text { resources towards the implementation of business } \\
\text { strategies. }
\end{array}
\end{aligned}
$$

The criteria of significance test in SPSS are displayed with the Anova table. The criterion for testing hypothesis simultaneously is; if the value of sig (a) is smaller than 0.05 then the null hypothesis $\left(\mathrm{H}_{0}\right)$ is rejected, meaning that there is a simultaneous influence from all dependent variables on the independent variable. The analysis results of the Anova test are:

Table 2. F Test Results With ANOVA

\begin{tabular}{|l|l|r|r|r|r|c|}
\hline Model & & $\begin{array}{c}\text { Sum of } \\
\text { Squares }\end{array}$ & \multicolumn{1}{c|}{ df } & \multicolumn{1}{c|}{$\begin{array}{c}\text { Mean } \\
\text { Square }\end{array}$} & \multicolumn{1}{c|}{ F } & \multicolumn{1}{c|}{ Sig. } \\
\hline 1 & Regression & 12000.679 & 2 & 6000.340 & 310.439 & $0.000(\mathrm{a})$ \\
\hline & Residual & 6668.351 & 345 & 19.329 & & \\
\hline & Total & 18669.030 & 347 & & & \\
\hline
\end{tabular}

Source : Results of Data Processing

In Table 2, it can be seen that the results of the analysis prove the value of sig. $<0.005$, so that the hypothesis stating that there is a simultaneous and significant influence of the industrial environment $\left(\mathrm{X}_{1}\right)$ and resources $\left(\mathrm{X}_{2}\right)$ on business strategy $\left(\mathrm{Y}_{1}\right)$. Further, to analyse the magnitude of influence contribution can beseen from the coefficient of determination. The value of $\mathrm{R}^{2}$ is in Table 3:

Tabel 3. The Simultaneous Influence of Industrial Environment and Resources Towards the Implementation of Business Strategy

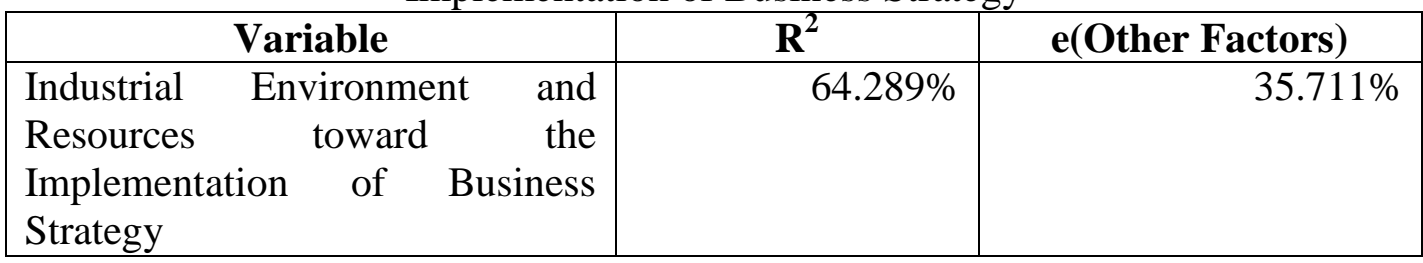

Source : Results of Data Processing

Based on the calculated coefficient of determination, it is known that the variables of industrial environment and resources simultaneously influence the business strategy implementation by $64.289 \%$ and other factors by $35.711 \%$. It indicates that the industrial environment and resources influence the business strategy implementation. A good industrial environment without being supported by the resources, it will not result a good business strategy. Simply stated, the more fulfilled the elements of industrial environment and 
resources variables, the more optimal the business strategy carried out by Manufacturing SMEs of food and beverageprocessing in West Java Province. To know the partial influence of the industrial environment $\left(\mathrm{X}_{1}\right)$ and resources $\left(\mathrm{X}_{2}\right)$ variables towards the business strategy implementation $\left(\mathrm{Y}_{1}\right)$, a statistical test is required. Hence, a statistical hypothesis will be used:

$$
\begin{array}{ll}
\mathrm{H}_{0}:\left(\rho_{\mathrm{yx}}\right)=0 & \begin{array}{l}
: \\
\text { There is no influence from the industrial environment } \text { or } \\
\text { resources towards the implementation of business strategies. }
\end{array} \\
\mathrm{H}_{1}:\left(\rho_{\mathrm{yx}}\right) \neq 0 \quad \begin{array}{l}
: \\
\text { There is influence from the industrial environment } \text { or resources } \\
\text { towards the implementation of business strategies. }
\end{array}
\end{array}
$$

With the test criterion: reject $\mathrm{H}_{0}$ if $\mathrm{t}$ count $>\mathrm{t}$ table

From the test results with the help of SPSS 22.00 computer program, it is obtained the results as listed in Table 4.

Table 4. Partial Testing of Industrial Environment and Resources Variables Towards the Implementation of Business Strategy

\begin{tabular}{|l|c|c|c|c|l|}
\hline Structural & $\begin{array}{c}\text { Path } \\
\text { Coefficient }\end{array}$ & $\begin{array}{c}\text { Total of } \\
\text { Influence }\end{array}$ & t count & t table & \multicolumn{1}{c|}{ Conclusion } \\
\hline$\rho_{\mathrm{y} x 1}$ & 0.284 & $10.851 \%$ & 8.744 & 1.960 & $\begin{array}{l}\text { Ho is rejected, there is } \\
\text { significant influence }\end{array}$ \\
\hline$\rho_{\mathrm{yx} 2}$ & 0.711 & $53.438 \%$ & 21.898 & 1.960 & $\begin{array}{l}\text { Ho is rejected, there is } \\
\text { significant influence }\end{array}$ \\
\hline
\end{tabular}

Source : Results of Data Processing

Further, the analysis of the magnitude of influence contribution is seen from the value of path coefficient. Based on the value of path coefficient, direct influence ofthe industrial environment variable towards business strategy implementation is $8.065 \%$. Meanwhile, indirect influence of the industrial environment variable through resources towards the business strategy implementation is $2.786 \%$. Hence, the total influence of the industrial environment variable towards the business strategy implementation is $10.851 \%$. The next path coefficient is resources variable towards the business strategy implementation. From the analysis results, it is known that the direct influence of resources variable towards the business strategy implementation is $50.552 \%$. Meanwhile, the indirect influence of resources variable through industrial environment towards the business strategy implementation is $2.786 \%$. The total influence of resources variable towards the business strategy implementation, both direct and indirect, is $53.438 \%$.

From the research results of this substructure, it can be concluded that the industrial environment (rivalry between competitors, new comers, supplier strength, customer strength, and substitute goods) positively influence, both simultaneously and partially, the implementation of business strategy. However, the results of the partial test show that the resources variable has the biggest contribution compared to the value resulted by industrial environment variable. It indicates that the resources have dominan influence toward the business strategy implementation, so it can be said that the provided resources should be 
taken into account when developing SMEs' business strategy in West Java Province. The relatively low ownership of resources cause the implemented business strategy will most likely not run optimally. Therefore, the adjustment between the resources and the business strategy implementation is indispensable. The results of this research empirically find that the resources factor is a valuable factor in deciding a company's success level in implementing a business strategy. Equally, the industrial environment has positive influence towards the business strategy implementation even its influence is not as high as that from the resources. This condition shows that an analysis towards an industrial environment, specifically to see how high its opportunities and challenges, is essential to implement a business strategy in SMEs company of food and baverage processing in West Java Province.

The influence of resources towards the business strategy implementation is higher compared to that of the industrial environment. It describes that the resources that support SMEs namely; tangible resources (financial resources, physical resources, human and organisation resources)and intangible resources (technology and information resources and innovation resources) have higher advantages compared to the support from the business environment. Therefore, the main focus of SMEs in West Java Province to increase their performance and competitive advantage is on the resources. According to Penrose in Sampurno (2010), creating knowledge and forming the basis of organisational growth are through the combination of the provided resources. Resources have a surplus value for a company that is as a tool for analysing the company to grow, as well as being one of the most dominant approaches to analyse sustainable competitive advantage (Bridoux, 2007). In addition, resources can help the company to implement competitive strategies that are appropriate to their strength and weakness based on the owned resources. Therefore, resources become the basis or foundation of the company before carrying out certain strategies.

The results of this research support and complete the research results of Anatan (2009) which show that the factors of business or industry environment influence manufacturing strategy choice. Therefore, the consideration towards the environment plays a significant role in deciding the manufacturing strategy choice. Meanwhile, the research results of Barokah (2009) show that the quality of strategic asset has a significant influencetowards the quality of competitive strategy. However, the results show that the resources factor is the third priority after Environmental Adaptability (priority 2) and Entrepreneurship Orientation (priority 1) in providing contribution to the quality of competitive strategy. Although there is a difference regarding the magnitude of the contribution with this research, its value still shows positive result. Hence, that it can be concluded that the previous research and this research are still relevant in supporting a number of theories from Pearce and Robinson (1997), Hitt, Michael, and Ireland, R. Duanne (2001) that resources are a key factor of success in creating a unique or special company as a source of competitive advantage in making strategic changes.

\section{Conclusions}

Industrial environment is several external factors of an organisation that provide opportunities and threats for SMEs of food and baverage processing. The results of the research prove that the industrial environment factor is relatively good in providing opportunitiesfor the growth of SMEs manufacturing in West Java Province. The 
organisational resources are an internal factor that includes strength and weakness factors. The analysis results prove that the resources (both tangible and intangible) owned by SMEs of food and baverage processing in West Java Province are relatively good and support the business development of manufacturing SMEs in this province. There is a positive significant influence of the industrial environment and resources on the business strategy of manufacturing SMEs in West Java Province, both simultaneously at $64.30 \%$, and partially, the resources' influenceis greater than the industrial environment's $(50.552 \%>10.851 \%)$.

The positive direction shows that observation on the industrial environment and the improvement of the quality of resources that is done by SMEs in West Java Province will enable SMEs to do the business strategy effectively and efficiently. This research finds that the industrial environment and resources provide a position for SMEs and influence the business strategy significantly,both partially and simultaneously. The magnitude of influence contribution is obtained from the resources variable. Based on the research results, to escalate the competitive advantage in obtaining maximal performance, resources provision is required. Therefore, SMEs are suggested to continuously strengthen the provided resources, so those resources can be competence. The concern of SMEs in West Java Province is expected to focus on the intangible resources. The intangible resources will be a source of greater competitive advantage compared to the tangible resources since resources such as knowledge, skill, and reputation will be difficult, and take a long time, to emulate.

\section{References}

Akbar, M. Taufik. (2015). "Upaya Pengembangan Usaha Kecil Menengah (UKM) Industri Krupuk Rengginang." Upaya Pengembangan Usaha Kecil Menengah (UKM) Industri Krupuk Rengginang. Jurnal 2(11): 1-7.

Barokah, Siti Nur. (2009). "Studi Tentang Faktor-Faktor Yang Mempengaruhi Kualitas Strategi Bersaing Untuk Meningkatkan Kinerja Perusahaan.” Universitas Diponegoro.

Bridoux, Flore. (2007). A Resources-Based Approach to Performance and Competition : AN Overview of the Connection Betweem Resources and Competition. Belgium: Institute Administratiuom et de Gestiom, Universite Catholique de Louvain.

C Elizabeth, S Baines. (1998). "Does Gender Affect Business 'Performance'? A Study of Microbusinesses in Business Services in the UK." Entrepreneurship \& Regional Development 10(2): 117-35.

Collis DJ. (1994). "Research Note: How Valuable Are Organizational Capabilities." Strategic Management Journal 1(15): 143-52.

Georgellis, Yannis, Joyce, Paul, and Woods, Adrian. (2000). "Entrepreneurial Action, Innovation and Business Performance: The Small Independent Business." Journal of Small Business and Enterprise Development 7(1): 7-17. http://www.emeraldinsight.com/journals.htm?issn=1462$6004 \&$ volume $=7 \&$ issue $=1 \&$ articleid $=873648 \&$ show $=$ html.

Hitt, Michael A, and Ireland, R. Duanne, Hoskisson. (2001). Manajemen Strategis, Konsep Daya Saing Dan Globalisasi. Jakarta: Salemba Empat.

Hunger, J.D. dan Wheelen, T.L. (2012). Strategic Management and Bussiness. Policy: Toward Global Sustainability (13th Edition). Pearson Prentice Hall.

Indris, Sofyan, and Ina Primiana. (2015). "Internal And External Environment Analysis On The Performance Of Small And Medium Industries ( Smes ) In Indonesia.” 4(04). 
Kemenperindag. (2019). "Kontribusi UMKM Naik.” Kompas.com.

Laitinen, E.K. (2002). "Dynamic Performance Measurement System: Evidence from Small Finnish Technology Companies." Scandinavian Journal of Management 18(2): 65-99.

Lia Anatan. (2009). Strategi Bersaing: Konsep, Riset, Dan Instrumen. 1st ed. Bandung: Alfabeta.

Mäki, K., and Pulkkinen, T. (2000). Barriers to Growth and Employment in Finnish Small Enterprises. Brisbane: ICSB Brisbane.

Njoroge, J K, W J Ongeti, and D Kinuu. (2016). "Does External Environment Influence Organizational Performance? The Case of Kenyan State Corporations." 3(3): 41-51.

Olarewaju, Abayomi, Information Technology, and Ayobami Folarin. 2012. "Impacts of External Business Environment on Organisational Performance in the Food and Beverage Industry." 6(2): 194-201.

Pearce, J.A. dan Robinson, R.B. Jr. (1997). Formulation, Implementation, and Control of Competitive Strategy. Boston: Irwin.

Porter. Michael E. (1998). From Competitive Advantage to Corporate Strategy. Harvard Business Review.

Primus, Josephus. (2019). "Makin Besar, Peran UKM Di Kawasan Asia Pasifik." https://ekonomi.kompas.com/read/2018/05/09/140904226/makin-besar-peran-ukm-dikawasan-asia-pasifik?page $=$ all .

Sampurno. (2010). Manajemen Stratejik: Menciptakan Keunggulan Bersaing Yang Berkelanjutan. Yogyakarta: Gadjah Mada University Press.

Sudjana. (2003). Teknik Analisis Regresi Dan Korelasi Bagi Peneliti. Bandung: Tarsito.

De Toni, A. dan S. Tonchia. (1998). "Manufacturing Flexibility: A Literature Review." International Journal of Production Research 36(6): 1587-1617. 